\title{
Iowa's Last Liquor Battle: Governor Harold E. Hughes and the Liquor-by-the-Drink Conflict
}

\author{
JERRY HARRINGTON
}

THE DEEP, RESONANT VOICE of Iowa Governor Harold E. Hughes echoed throughout the packed Iowa House chamber on January 17, 1963, as he finished his half-hour inaugural address. Facing an audience that included all of Iowa's representatives and senators in Des Moines for the new legislative session, the recently elected Democrat had just proposed an aggressive agenda for the overwhelmingly Republican legislature.

It was the speech's final flourish, however, that so captured the nature of the new governor, a political personality many Iowa legislators were just beginning to size up. "It is sometimes said that the knack of skillful government is to hang back, do as little as possible, and make no mistakes," Hughes said. "I hope there is another way-for between you and me, this prospect does not invite my soul." Promising to "experiment and make some mistakes," Hughes pledged to actively engage with legislators to reform Iowa's political landscape. Many of the Iowa politicians listening to these words undoubtedly believed that Hughes would apply this dynamic attitude to an issue that was on everyone's mind and had been at the core of his campaign for governor - the question of liquor by the drink in Iowa. ${ }^{1}$

1. "Harold Hughes, Inaugural Address, 1/17/63," Speeches-Oct. 1962-Jan. 1963, box 27, Harold E. Hughes Papers, Special Collections, University of Iowa Libraries, Iowa City, Iowa (hereafter cited as HEH Papers); Des Moines Register, $1 / 18 / 63$.

THE ANNALS OF IOWA 76 (Winter 2017). (C) State Historical Society of Iowa, 2017. 
Political analysts at the time generally interpreted Hughes's 1962 election victory over incumbent Republican Governor Norman Erbe as a referendum on liquor by the drink. Citing widespread violations of the prohibition of over-the-counter liquor sales, Hughes had aggressively campaigned on allowing purchase of liquor drinks in bars, social clubs, and other establishments, complementing the existing legal sale of liquor by the bottle through state monopoly liquor stores. Either change the law or, Hughes pledged, he would enforce the current one. To do otherwise, he said, shows disrespect for all laws. To pass such a reform, however, the new governor would need to overcome resistance from a conservative, rural-based legislature that had long blocked the change. The debate across Iowa in the 1962 gubernatorial campaign and the subsequent legislative approval of liquor by the drink dominated Iowa politics for nearly a year.

The liquor-by-the-drink question, however, was more than just a single campaign issue and legislative debate. The episode marked the culmination of more than a century of political conflict within Iowa over its citizens' access to alcohol. Beginning with the state's first General Assembly, Iowans and their elected officials had argued passionately over the issue, prompting solutions ranging from outright prohibition to limited licensing of liquor sales in saloons to the sale of bottled liquor through state stores. Legalizing liquor by the drink in 1963 effectively ended that debate; it was the last political conflict in Iowa when the terms wets and drys were used. With that action, Iowansthrough their elected representatives-came to accept legal liquor sales in both bottle and glass, as long as the state enforced strict licensing laws and regulated the practice. If state and local governments collected fees from licenses and taxes, that was an added benefit. Political debates after this point were not over whether liquor should be openly sold but over such issues as the minimum drinking age, allowable alcohol levels for drivers, and whether bottled liquor should be sold through state monopoly stores or private businesses. Since 1963, limiting liquor sales to the general adult population has not been a viable political issue in Iowa. ${ }^{2}$

2. This article focuses primarily on the politics of the liquor-by-the-drink issue. It does not attempt to review the religious, moral, ethno-cultural, or social 
By the early 1960s, a majority of Iowans - at least according to opinion polls-favored liquor by the drink. ${ }^{3}$ The roadblock was the Iowa legislature-especially, many said, the Housewhich was fundamentally apportioned by geography, not population, and dominated by more conservative rural interests. Hughes's win and his successful effort to enforce existing liquor laws put intense political fire under the feet of recalcitrant legislators. These and other factors prompted enough of them to modify their attitudes and support the change, ending this part of the state's long-standing liquor argument.

This episode reflects a transitional moment in Iowa history, a shift from a rural state to an urban one. For the first time, the 1960 federal census showed more Iowans living in "urban" areas than in "rural." An expanding urban population, with its greater acceptance of liquor consumption, was overpowering more conservative rural opposition to easy access to alcohol. The liquor reformers' triumph exemplifies the rise of Iowa's urban interests. ${ }^{4}$

LIQUOR ISSUES have been debated in Iowa for as long as it has been a state. The first Iowa General Assembly in Iowa City passed liquor control legislation in February 1847, giving county residents the option to vote on whether or not commissioners could grant liquor licenses in each county. In elections held in the frontier state on April 5, 1847, every established county except Keokuk voted to prohibit liquor sales, but the prohibition was often overlooked, and commonly merchants either secretly

conflicts that accompanied this long-standing and hotly debated issue among Iowans. All of those aspects of the historical liquor debate in Iowa are certainly important, but this study leaves those to other scholars. Iowa churches and religious groups are part of this discussion but only as lobbying and pressure groups that sought to affect the debate. I use the terms wet and dry, which were commonly used in liquor debates. Wets refers to those who supported expanded liquor availability; drys were those who wanted to limit liquor use.

3. Des Moines Register, 5/13/1962.

4. U.S. Census Bureau, Census of Population and History, Census of Population: 1960-VI-Part 17, General Population Characteristics - Iowa. According to the 1960 census, 53 percent of Iowans lived in urban areas and 47 percent in rural areas. The 1950 census had recorded 47.6 percent of Iowans in urban areas and 52.4 percent in rural. The U.S. Census Bureau defined rural residents as anyone living outside of urban areas with a population of 2,500 or more. 
or openly sold liquor illegally. By the early 1850s, the Maine Law, named after a state prohibitory law passed in Maine in 1851, was the rallying cry of prohibition forces and became part of the Whig Party platform in 1854 . The next year, with the Iowa legislature under Whig control, both Iowa houses passed a law prohibiting the sale of liquor in Iowa and Whig Governor James Grimes signed it. On April 2, 1855, Iowa voters approved the law, 25,555 to 22,645 . But, according to historian Dan Elbert Clark, local officials "simply folded their hands and paid little heed to its enforcement." In 1857 the General Assembly, responding to that reality, passed a liquor licensing law, allowing sales that would happen anyway, although prohibition remained on the books. Especially with the influx of German immigrants into the state, Clark notes, "prohibition seemed to fall into disfavor," and by the 1860s "liquor was sold almost without restrictions." 5

Activists rallied in 1877 with a prohibition candidate for governor who called for the law's enforcement. He garnered more than 10,000 votes in a losing cause. That campaign-through speeches, correspondence, newspaper coverage, and networking throughout the state-helped revive the temperance movement and expanded support for curbs on liquor traffic. The next year, at the Woman's Christian Temperance Union (WCTU) convention in Burlington, J. Ellen Foster, who chaired the committee on legislation, proposed amending the Iowa Constitution to prohibit liquor. That, she argued, would make prohibition a permanent part of Iowa law, removing it from the changing winds of yearby-year politics. That effort gained enough popular support to prompt Iowa General Assemblies in 1880 and 1882 to pass a constitutional amendment banning the manufacture and sale of intoxicating liquor, including ale, wine, and beer. In June 1882 Iowa voters approved the prohibition amendment, 155,436 to 125,677 , with 75 counties voting in favor. However, a Scott County district court that fall declared the amendment invalid on a technicality, because the amendments passed by the two sessions of the Iowa legislature had slightly different wording.

5. Dan Elbert Clark, “The History of Liquor Legislation in Iowa, 1846-1861," Iowa Journal of History and Politics 6 (1908), 55-87; idem, "The History of Liquor Legislation in Iowa, 1861-1878," Iowa Journal of History and Politics 6 (1908), 33974 . 
The Iowa Supreme Court upheld the decision in 1883, throwing the prohibition amendment out of the Iowa Constitution. ${ }^{6}$

Not wanting to begin the long, multiyear amendment process again, prohibition supporters in the Iowa General Assembly passed a law banning intoxicating liquor in Iowa. The law went into effect on July 4, 1884, but despite attempts at enforcement, many cities, especially Iowa river towns, ignored it. According to Clark, "It is a commonly known fact that in many cases municipal and county officials were elected solely on the condition that they would not attempt to enforce the prohibitory law." 7

The issue became a centerpiece of the 1889 gubernatorial race, resulting in the election of Iowa's only Democratic governor between the Civil War and the Great Depression: Horace Boies, who opposed prohibition. Iowa Republicans, who could certainly read election returns, eventually reached a legislative compromise in 1894, passing the unusual Mulct Law. While keeping prohibition on the books, it allowed merchants to sell liquor as long as they paid fines, or "mulct taxes," for breaking the law. Prohibition remained the rule and violations the legal exception. ${ }^{8}$

In 1909 the General Assembly passed the Moon Law, named after its sponsor, Senator Edwin Moon. The act limited saloons to one for every 1,000 inhabitants in a community; towns of fewer than 1,000 were allowed a single seller, and, in communities with more than one already existing saloon per

6. Clark, "History of Liquor Legislation, 1861-1878," 339-74; Dan Elbert Clark, "History of Liquor Legislation, 1878-1908," Iowa Journal of History and Politics 6 (1908), 503-608. To amend the Iowa Constitution, two consecutive sessions of the Iowa legislature must pass an amendment through both houses; then the amendment must be approved by Iowans in a popular vote. In this case, however, the 1882 session of the legislature passed a version of the prohibition amendment that omitted the phrase "or to be used" between "No person shall manufacture for sale, or sell, or keep for sale, as a beverage" and "any intoxicating liquor whatever, including ale, wine and beer" that was in the 1880 version. The courts ruled that passing two different wordings of the amendment violated the process and tossed out the amendment. The courts also ruled that the Iowa House had not completely followed the rules in recording the amendment in its journal, making the amendment invalid.

7. Clark, "History of Liquor Legislation, 1878-1908," 503-608.

8. Ibid. For a summary of the Iowa prohibition debate in the 1880s and ' 90 s that includes ethnoreligious alignments, see Richard Jensen, "Iowa, Wet or Dry? Prohibition and the Fall of the GOP," in Iowa History Reader, ed. Marvin Bergman (Iowa City, 1996), 263-90. 
1,000 residents-mostly Iowa river towns-the law allowed those establishments to continue. As a result of the Moon Law, the number of Iowa businesses selling liquor was cut in halffrom 1,600 in 1908 to 740 in 1912. Another law passed in 1909 made it unlawful for any person or corporation engaged in the "manufacture, brewing, distilling or refining of intoxicating liquors" to be involved, either directly or indirectly, in the retail liquor business. ${ }^{9}$

The Mulct Law lasted until 1915, when vital portions of it, such as those addressing payment and collection of the mulct tax, were repealed, effectively killing it. According to Clark, that move was a "spontaneous expression of the quiet convictions of the people of the State, rather than a response to an active, organized demand." The prohibition statute, still on the books, remained state law and established policy, and the legislature increased penalties for violations, together with providing additional means for enforcement. This marked the third time in Iowa's history that absolute prohibition of liquor was state law. ${ }^{10}$

The Iowa legislature passed another constitutional amendment on prohibition in two sessions in 1915 and 1917, with a statewide vote set for October 15, 1917. This time, however, Iowans rejected placing prohibition into the constitution, voting down the effort by 932 votes among over 430,000 cast, the first time Iowans vetoed prohibition by popular vote. Soon, however, national prohibition became the law of the land with passage of the Eighteenth Amendment to the U.S. Constitution. ${ }^{11}$

With the repeal of national prohibition in 1933-an action Iowans supported in a statewide popular vote on the federal Twenty-First Amendment, 377,275 to 249,943-state political leaders faced the challenge of responding to liquor use in Iowa in a post-prohibition age. The solution was the creation in 1934 of an Iowa liquor monopoly, which sold-and controlledalcohol through state stores managed by the State Liquor Control Commission. The only alcohol Iowans could legally pur-

9. Dan Elbert Clark, "Recent Liquor Legislation in Iowa," Iowa Journal of History and Politics 15 (1917), 48-50.

10. Ibid., 57-58.

11. Edgar Rubey Harlan, A Narrative History of the People of Iowa, 5 vols. (Chicago, 1931), 2:274. 
chase and possess was sold through the state stores. Iowans who wanted to buy liquor for consumption off the premises had to buy permits, and each purchase was registered with the state. Store managers held the right to refuse purchases to individuals they felt would abuse the privilege. (Prior to repeal, beer in Iowa was already legal and had a different distribution system. In early 1933 Congress passed legislation redefining "intoxicating" under the Eighteenth Amendment, stating that this did not include beer with a 3.2 percent alcohol content or less. Iowa lawmakers followed suit on April 15, approving the same definition on the state level for "beer, ale, porter, stout or any other malt liquor" and setting up regulatory guidelines for beer brewers, bottlers, wholesalers, and retailers. Retailers with state permits could sell beer in stores and serve it over the counter in glasses in establishments that became known in Iowa as "beer taverns." By law, "intoxicating" liquor could not be sold in taverns; nor could it be found on the seller's premises.) ${ }^{12}$

By the mid-1950s, some Iowans were clamoring for more liberalized liquor access laws, specifically the right to enjoy intoxicating beverages outside the home with friends and neighbors at local venues. Iowa legislators acceded to this demand in 1955 when they passed legislation allowing for "key clubs." These establishments-social settings such as country clubs, VFWs, Elks clubs, American Legion halls, and others - were allowed to set up lockers where members could place bottles of alcohol purchased from the state liquor stores; each member was given a key to a locker and, when visiting, could take out bottles and consume alcohol on the premises. The establishment itself could not legally supply liquor, either by bottle or glass. ${ }^{13}$

By the early 1960s, the legal framework in Iowa for alcohol sales centered on the state liquor stores, which sold to Iowa citizens; by that time, there were nearly 190 stores throughout Iowa. Liquor consumption was legally allowed in key clubs as long as the bottles were brought into clubs by consumers, not club managers or owners. Liquor by the drink-serving alcohol in

12. Leland Sage, A History of Iowa (Ames, 1974), 301-2; Daniel Okrent, Last Call: The Rise and Fall of Prohibition (New York, 2010), 352; 1933 Laws of Iowa, 53-62; 1933-1934 Laws of Iowa, 38-60.

13. 1955 Laws of Iowa, 108-9; Cedar Rapids Gazette, 12/26/1962. 
glasses and charging for the service-was illegal in the state, although, by this time, it was legal in all states surrounding Iowa. Bills calling for legalizing liquor by the drink had been introduced in nearly every session of the Iowa legislature in various forms since World War II, but was seriously debated only once: in 1961 a bill came to the floor of the Iowa House, was debated, and soundly defeated, $72-22 .{ }^{14}$

As most Iowans knew, however, the practices in their communities did not reflect the laws on the books, which were commonly violated across the state. In 1962 the fiction of Iowa's liquor laws was about to collide head-on with the reality of a heated gubernatorial campaign.

ON SUNDAY MORNING, May 6, 1962, Iowans woke to read a banner headline in the Des Moines Sunday Register: "'Liquor By Drink' in 2/3 of Iowa!" According to a story written by Register reporter George Mills, assisted by a staff of reporters, liquor was sold by the drink in at least 66 of Iowa's 99 counties, counties with 2.2 million of the state's 2.8 million residents. Register reporters had combed the state to "make available the facts about liquor law observance in Iowa." They found that "sale of liquor by the drink has been more or less commonplace in even small towns." "In most county seats," wrote one reporter, "you don't need your own bottle. All you need is the money, and courage enough to walk into a club and ask for bourbon, after telling the bartender you are sick of beer." In some cases, wrote Mills, local law enforcement officials did not "crack down" on violators because they believed a majority of citizens opposed enforcing the law or did not care one way or the other; those officials were often elected and re-elected several times. The Register listed a county-by-county summary of eastern Iowa counties, citing whether or not they offered illegal liquor sales; western counties were listed in a follow-up story a week later. ${ }^{15}$

14. Twenty-Eighth Annual Report of the Iowa Liquor Control Commission for Fiscal Year Ending June 30, 1962, p. 6; Cedar Rapids Gazette, 1/20/1963; Sioux City Journal, 12/8/1962.

15. Des Moines Register, 5/6/62, 5/13/62. The Register reported that establishments were not afraid of local or state crackdowns, but they were of federal law enforcement. Those selling liquor were required to buy a federal Retail Liq- 
The defiance of the liquor-by-the-drink prohibition reflected public opinion in Iowa. In May 1962 the Des Moines Register reported the results of an Iowa Poll: 55 percent of Iowans favored changing state laws so that liquor by the drink could be sold legally in Iowa; 37 percent were opposed. This public stance had not altered significantly in recent years; in a 1957 survey 54 percent of Iowans had favored the practice, and 52 percent had in 1959. The 1962 poll showed that "city" residents strongly favored a change (62 percent), but only 42 percent of "farm" residents reacted positively; 52 percent of those in "towns" favored open liquor sales, with 41 percent opposed. Rural Iowans consistently opposed liquor by the drink. ${ }^{16}$

The disparity between city and farm was part of the difficulty in translating popular will on the liquor issue into legislative change. The Iowa legislature was dominated by rural forces, set by a reapportionment plan established in 1904, when legislators passed a constitutional amendment creating a House with 108 members, one from each of Iowa's 99 counties, with an additional member granted to each of the nine most populous counties. The 50-member Senate was apportioned by population, but in 1928 another amendment prohibited counties from having more than one senator; even as counties with large urban populations grew in twentieth-century Iowa, their Senate representation was limited. Both chambers - but especially the Housevastly underrepresented urban interests. For instance, by 1960, the six least populated counties (Adams, Ringgold, Clarke, Davis, Van Buren, and Wayne) had a total of six members in the Iowa House, representing 52,377 people. The three most populous counties (Polk, Linn, and Black Hawk) also had six members in the House, but they represented 525,696 Iowa citizens, nearly ten times the constituency of the bottom six counties.

uor Dealer (RLD) stamp for \$54 per year. Between July 1, 1961, and publication of the Register story, 1,784 privately operated Iowa establishments had bought RLD stamps. The maximum penalty for selling liquor without a federal stamp was two years in prison and a $\$ 5,000$ fine. Those businesses had federal approval for an activity that was illegal in Iowa. The Register also pointed out that there were 4,700 taverns with Class B beer permits, allowing consumption of beer on the premises. Most of the managers of those taverns, claimed the reporters, did not sell liquor by the drink and opposed it, seeing it as competition for their businesses and putting them on the same side of the argument as the "drys."

16. Des Moines Register, 5/13/1962. 
Urban legislators were simply vastly outnumbered by rural legislators in the Iowa House. Given that liquor by the drink traditionally had low support among rural Iowans, the construction of the Iowa legislature was a high hurdle for those supporting a loosening of Iowa liquor laws. ${ }^{17}$

In the early 1960s, the Iowa Republican Party dominated the state legislature; in the 1961 session of the General Assembly 78 of 108 seats in the House and 35 of 50 seats in the Senate were Republican. The party's establishment was traditionally hesitant to change liquor laws - at least according to its statewide public pronouncements. When Iowa Republicans met at Veterans Auditorium in Des Moines on July 20, 1962, to pass a platform and mark the beginning of the campaign for state offices, Iowa GOP members voted simply to study the issue of liquor by the drink, urging the legislature to undertake a "re-evaluation and re-approval" of the "present liquor control act."18

THE IOWA DEMOCRATIC CANDIDATE for governor, Harold E. Hughes, did not share that attitude. He supported legalizing liquor by the drink. Born in 1922 in the small western Iowa town of Ida Grove, Hughes was a star high school athlete; he won the state discus championship in 1938 and was selected as all-state football guard in 1939. He attended the University of Iowa for a year and played on its football team. Marrying Ida Grove native Eva Mercer in 1941, he dropped out of college and worked a series of jobs until he was drafted into the military during World War II. He fought in the battle to take Sicily and Salerno in Italy in 1943. After military service, he returned to Ida Grove, where he got a job driving trucks; he then managed Hinrichs Truck Line in Ida Grove and later worked as a field representative for the Iowa Motor Truck Association. Dissatisfied with the low rates independent truckers were getting for hauling freight, he organized them into the Iowa Better Trucking Bureau.

17. Charles Wiggins, "The Post World War II Legislative Reapportionment Battle in Iowa Politics," in Patterns and Perspectives in Iowa History, ed. Dorothy Schwieder (Ames, 1973), 403-430; Iowa Official Register, 1963-1964 (Des Moines, 1964), 303-4.

18. Des Moines Register, 7/21/1962; Iowa Official Register, 1961-1962 (Des Moines, 1962), 96. 
As the head of the bureau, he butted heads with members of the Iowa State Commerce Commission. In 1958 he ran for one of the three statewide commission posts and was elected. Initially a Republican, Hughes grew disenchanted with the party's conservatism and became a Democrat prior to his election as commissioner. He ran for governor simply because he thought he could do a better job than any other candidate running. He lost the primary on his first try in 1960 but won in 1962. ${ }^{19}$

To those who supported him in his race for governor in 1962, Hughes was a magnetic personality who often acted in ways contrary to those of a traditional politician, frequently forceful, charismatic, and direct. He was initially an awkward candidate, uncomfortable with small talk and light chatter. As he said, "I don't run up and down the street shaking hands because I don't believe it does much good." He was much more comfortable directly addressing the issues in blunt, stark terms in his speeches and conversations. A large man, 6'2" tall, Hughes was handsome with a full head of dark hair. One of his strengths was his personal delivery: his deep, baritone voice commanded attention. According to longtime Des Moines Register political journalist James Flansburg, Hughes delivered "the most telling and moving oratory I've ever heard." 20

Hughes was also a deeply religious man. He experienced a "born-again" Christian spiritual transformation in 1952 when in the depths of personal despair. His desolation rose from a serious problem with alcoholism that almost destroyed his marriage and led him to the brink of suicide. Following a drinking binge after his wife and daughters had left him, he sat in his bathtub with a gun in his mouth, ready to pull the trigger, when, he later claimed, he had a religious experience. At that point, he vowed

19. For Hughes's personal story, see his autobiography, Harold Hughes with Dick Schneider, Harold E. Hughes: The Man from Ida Grove: A Senator's Personal Story (Lincoln, VA, 1979). As the title suggests, much of the narrative centers on Hughes as a person, especially the impact of his Christian faith on his life, rather than on politics. For a more expansive outlook on Hughes and Iowa politics, as well as the impact of his dynamic personality, see Jim C. Larew, A Party Reborn: The Democrats of Iowa, 1950-1974 (Iowa City, 1980), especially the chapter on Hughes, "The Democrats Reborn: The Rise of Harold Hughes," pp. 73-126.

20. Iowa Official Register, 1962-1963 (Des Moines, 1964), 4; Des Moines Register, 10/7/1962, 11/7/1962; New York Times, 10/25/1996. 


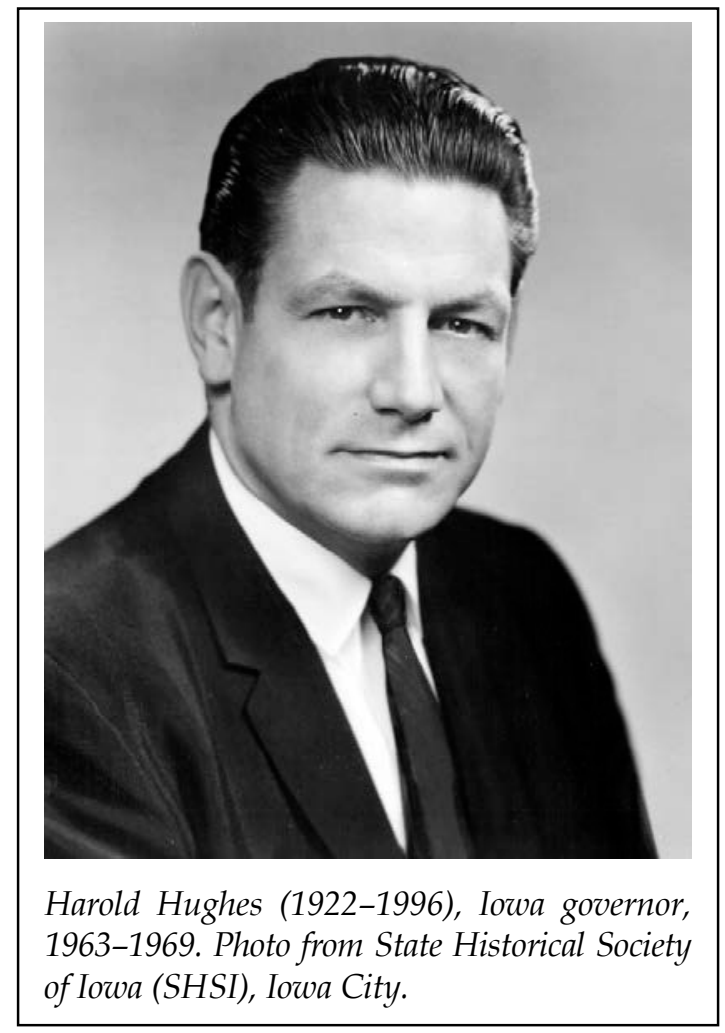

to give up alcohol, sought help, and became intensely involved in the Methodist church, even volunteering as a Sunday school teacher. Hughes was open about his alcoholic past, discussing it freely when asked about it on the campaign trail. He was careful to say that he was a recovering alcoholic, not a cured one. ${ }^{21}$

Soon after the Des Moines Register exposé on statewide liquorby-the-drink violations and after several weeks of careful study, Hughes announced that he backed legalization. Accepting the Democratic nomination at the State Democratic Convention on July 28, 1962, he called it a moral issue.

It is a moral issue because it involves an issue of official hypocrisy that shames the entire state. The real issue is not whether or not we shall have "liquor-by-the-drink" in Iowa. Let's face it. You

21. Hughes, Harold E. Hughes, 102-9; Cedar Rapids Gazette, 11/7/1962; Des Moines Register, 10/7/1962. 
know and I know and every honest person in Iowa knows that we have liquor-by-the-drink in this state now. . . . The moral issue, then, is: Shall we straight-forwardly legalize the sale of liquor-bythe-drink, enforce the law and really control the liquor traffic in this state? Or shall we perpetuate the present wide-open key club system that subsidizes the bootleggers and racketeers with revenues that rightfully belong to the taxpayers of Iowa? ${ }^{22}$

Hughes also attacked the incumbent governor for mishandling the state budget, allowing a $\$ 46$ million surplus inherited from the prior administration to shrink to $\$ 18$ million. Citing capital improvement needs throughout the state, Hughes proposed raising new revenues to meet those needs and to provide for property tax reform to relieve those stressed on the local level. Looking forward to an aggressive fall campaign, Hughes said, "What can happen in these three months can shake this state out of its coma as it has never been shaken before and get it on the forward move again." 23

OPPOSING HUGHES was the incumbent Republican governor, Norman Erbe of Boone, running for his second two-year term. The youngest of six children of a Boone Lutheran minister, Erbe had served on 35 combat missions with the Eighth Air Force during World War II and was awarded the Distinguished Flying Cross and four air medals. After earning a law degree from the University of Iowa in 1947, he practiced law in Boone, served as county attorney, and chaired the Boone County Republican Party from 1952 to 1956. Elected Iowa attorney general in 1956, Erbe gained a second term by little more than 2,000 votes two years later. On September 1, 1959, he sought to raise his statewide profile by reaching back to an 1886 Iowa law and announcing that he was banning 42 "girlie" magazines as obscene literature. The action did little to actually change magazine availability, but the controversy and publicity helped Erbe win a close GOP gubernatorial primary in 1960, and in November he was elected governor.

22. Cedar Rapids Gazette, 11/8/62; "Press Release for Democratic Fund Raising Dinner, Newton," 5/26/1962, Press Releases 1962, box 25, HEH Papers; "State Democratic Convention, July 28, 1962," Speeches-July-Sept. 1962, box 27, HEH Papers.

23. Ibid. 


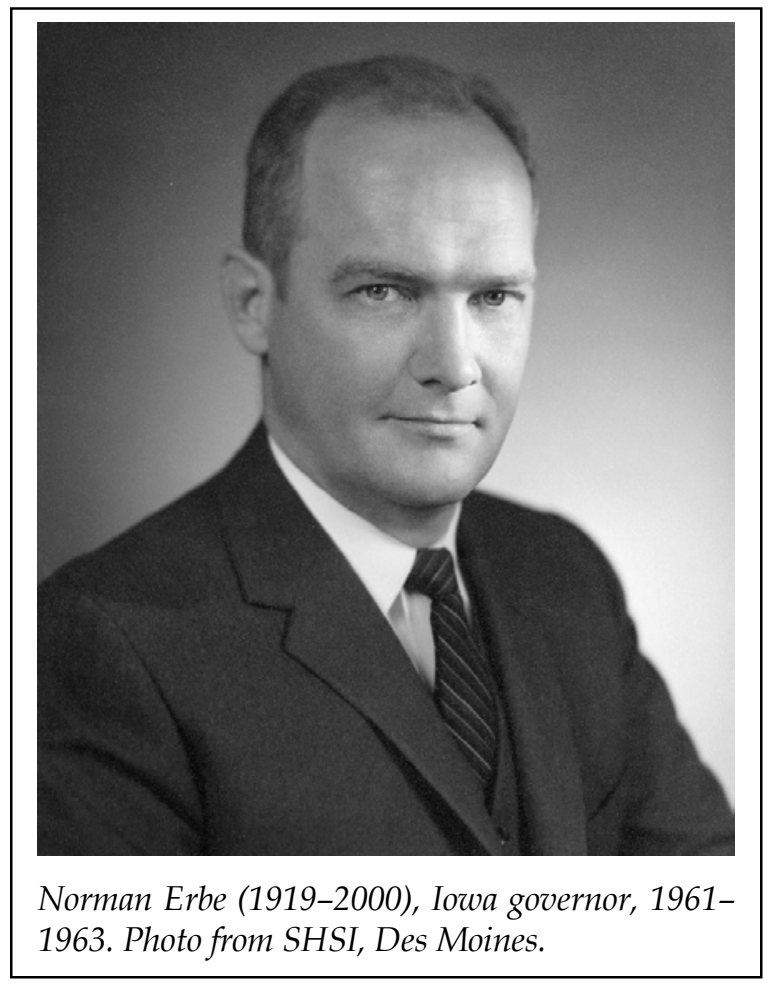

Erbe's strategy during his re-election bid in 1962 was to avoid making waves. The Iowa legislature, not the governor, he argued, makes the laws. "I don't want to come out whole hog for this position or that if it doesn't materialize in the Legislature, "he said. "There's no use doing this unless you know you have the votes. . . My concept of the governorship is that of an administrator and executive through persuasion. In our weak governor system, it's impossible for the governor to impress his will if the Legislature or government departments don't want to follow." Erbe said that the liquor-by-the-drink issue was up to the Iowa General Assembly; he wasn't going to push the issue. He claimed to be guided by the state Republican platform, which only said that the issue should be "studied." He refused to go further than that. ${ }^{24}$

24. Des Moines Register, 10/14/1962; Iowa Official Register, 1961-1962, 4. Iowa's "weak governor" stems from the Iowa constitutional provisions allowing for 
As the campaign progressed, this conservative stance seemed a safe bet for Erbe. In the first poll on the race conducted by the Des Moines Register and released on October 7, Erbe led Hughes, 49 to 42 percent, with the rest undecided. Among "city" voters, Erbe led 46 to 44; among "town," 50 to 41; and among "country," 53 to 38 . However, the polling numbers included an ominous sign for the Erbe campaign: when Iowans were asked who would do the best job on "liquor," Hughes led 46 to 30 percent. ${ }^{25}$

There were indications around the state that opinion on the liquor-by-the-drink issue was divided along urban/rural rather than partisan lines. At the Polk County Republican Party convention, delegates representing the most populous county in the state passed a resolution in favor of liquor by the drink under strict regulation. The resolution "deplored" the "almost complete disregard of the present Iowa liquor laws which permit the operation of phony key clubs." County Republican meetings in Pottawattamie and Des Moines counties approved similar planks. ${ }^{26}$

Among the businesses at the forefront of the issue-restaurant owners - the consensus was that it was time for a change, according to Register reporter Nick Lamberto, covering the annual meeting of the Iowa Restaurant Association in Des Moines. Ermol Loghry of Iowa City, newly elected treasurer of the organization, said, "The way we're bringing up children now to wink at the law is not right. ... We've had 30 years of handling liquor the way it is now. Thirty years is long enough to see if it can be enforced." Others at the meeting said it was unfair to businesses close to the rivers on either side of the state because those in Nebraska and Illinois could serve liquor legally. ${ }^{27}$

Hughes aggressively raised the issue everywhere he spoke around the state during the 1962 fall campaign. In Erbe's home

several other Iowa state executive posts elected independently of the governor. These included, at the time, the lieutenant governor, the attorney general, the secretary of state, the state treasurer, the state auditor, and the secretary of agriculture. The Iowa Constitution would later be amended to allow a gubernatorial candidate to select, with the consent of the party convention, a lieutenant governor candidate who would serve if elected.

25. Des Moines Register, 10/7/1962.

26. Des Moines Register, 6/30/1962, 7/3/1962.

27. Des Moines Register, 10/16/1962. 
town of Boone, Hughes asked, “Why hasn't Mr. Erbe done anything about the shocking statewide, open violations of the state liquor control laws?" In Davenport, he said, "Since we have it [liquor] anyway, why not have the profits go to the taxpayers?" Estimating that legalization could bring in as much as \$15 million per year, Hughes argued that the revenue could be put to good use for state capital improvements, though he was careful to say that the issue was one of respect for law, not revenue enhancement. "To restore respect for our laws is our first objective. The revenue issue is secondary - but it is nonetheless important and worth considering." Addressing "drys," Hughes argued,

Many good temperance people frown upon liquor tax revenue as being 'tainted' money. I appreciate the sincerity of their viewpoints but it is high time we faced realities. The state is already in the liquor business through package sales in the state stores. The state tax commission-amazingly enough-admits that it collects some sales tax revenue from illegal liquor-by-the-drink sales in key clubs! If the revenue is tainted, we are already tainted. Moreover, the full measure of revenues from taxing by-the-glass should go to the taxpayers to whom such revenues rightfully belong, rather than largely bootleggers and racketeers as is the case at the present time.

As governor, Hughes pledged on October 3 in a front-page Register story, he would enforce the current law prohibiting liquorby-the-drink sales "whether the law is changed or not." 28

Recognition of the need for additional state revenue arose when the Des Moines Register interviewed members of the bipartisan Iowa Legislative Revenue Study Committee and reported the group's consensus that $\$ 30$ million was needed just to maintain present expenditures and the current rate of development at the state colleges. Additional funds would also be needed for proposed property tax relief. This further raised the profile of revenue from liquor sales that Hughes continued to stress. He added that he would urge a combination of sources - increased sales tax, a broadened sales tax, or increased state income taxto meet the state's needs. Erbe's response was that he would not

28. "Remarks at Boone, Iowa, Sept. 1, 1962," Speeches July-Sept., 1962, box 27, HEH Papers; Des Moines Register, 10/3/1962, 10/13/1962, 10/30/1962. 
make any recommendations until after the committee made its final report, which would be after the election. Hughes accused Erbe of using that to duck the issue. ${ }^{29}$

Calling Erbe "the Great Vacillator," Hughes pounded his opponent for not generating a plan for property tax relief or enforcing the state's liquor laws. Speaking in Denison, Hughes blamed Erbe for the problem. "The plain facts are that as governor ... and as attorney general for years, he himself is more responsible than anyone else for the wide-open illegal liquor traffic in this state that corrupts our young people and makes a mockery of our laws." Hughes scoffed at Erbe's argument that Iowa's "weak governor" system made the governor answerable to the legislature, calling it a "curious spineless concept of the governor's role." "The executive branch has always had the necessary authority - and the responsibility - to enforce the law," Hughes claimed. "As usual, Mr. Erbe passes the buck on liquor law enforcement to the legislature-but this is an absurd excuse. Under our system, the legislature makes the laws; the executive branch is supposed to carry them out. The weakness in the 'weak governor' system is Mr. Erbe himself." 30

As the campaign moved on, several "dry" supporters saw the climate beginning to change and concluded that they needed to take a stand in the debate. In late October, the Greater Des Moines Evangelical Ministers Association passed a resolution opposing liquor by the drink. The group, representing 50 Des Moines churches, argued that "alcohol-caused expenses will cost a state from $\$ 1.33$ to $\$ 5.75$ for every dollar collected on liquor tax" and that, among the six surrounding states with liquor by the drink, "liquor consumption is more than 47 percent higher than in Iowa." On October 21, the Temperance Legislative Council, a lobbying group with members from the Iowa WCTU, the Iowa Temperance League, and the Iowa Council of Churches, announced its support for Erbe. Responding to potential opposition to his position from church pulpits, the Hughes campaign

29. Des Moines Register, 9/16/1962, 9/26/1962.

30. "Press release, Oct. 2, 1962, speaking at a Democratic barbeque in Denison," Press Releases 1962, box 25, HEH Papers; "Press release on speech in Fort Dodge on Oct. 15, 1962," Press Releases 1962, box 25, HEH Papers; Des Moines Register, 10/3/1962. 
in October sent a letter signed by the candidate to more than 1,000 Iowa clergy, explaining his stand on liquor by the drink. Addressing the "thousands of good people who oppose any change in the liquor laws because of temperance convictions," Hughes wrote that his advocacy of liquor by the drink is not "simply another chapter in the wet-dry issue. It isn't. It is an issue of law and order over crime and confusion. It is an issue of honesty over hypocrisy." More directly, Hughes said in a speech in Corning, "It is time that the temperance people in Iowa opened their eyes and looked at reality." 31

With the campaign moving into its final month, Erbe stressed that it was important for Iowans to elect a Republican governor to work effectively with an overwhelmingly Republican legislature. Erbe argued that Hughes was irresponsibly overestimating the role of a governor in the legislative process. "Any candidate who says his election will mean any bill will be passed is being considerably less than honest with the voters," he said in Harlan. "The lawmaking rights of our state are only within the domain of the legislature." Hughes responded that Erbe was taking credit for past legislation while claiming that he could not influence legislation in the future. ${ }^{32}$

In a mailing to the state's 945 Iowa mayors that was widely publicized in the Iowa media, the Hughes campaign pointed out that per capita liquor sales in state stores were substantially lower in most of the state's eastern and western border counties than in interior counties (where the average was $\$ 20.80$ versus $\$ 14.56$ in the eastern counties and \$11.99 in the west). The point was that substantial quantities of liquor were brought illegally into Iowa from neighboring states to serve the liquor-by-thedrink market. Iowa counties and towns were not getting that revenue from state liquor stores. "Iowa should either get out of the liquor business or get into it right," Hughes said, adding that "cities, towns and counties should share in these extra monopoly store profits and in license fees." 33

31. Des Moines Register, 10/17/1962, 10/21/1962, 10/27/1962; "Press release on speech in Corning, Oct. 23, 1962," Press Releases 1962, box 25, HEH Papers.

32. Des Moines Register, 11/1/1962, 11/2/1962, 11/3/1962; Cedar Rapids Gazette, 11/2/1962.

33. Des Moines Register, 11/2/1962; Cedar Rapids Gazette, 11/2/1962. 
Erbe obtained the Des Moines Register's endorsement on October 28. Its editorial writers believed that the incumbent could get more done because Republicans dominated the legislature, which would block efforts supported by Hughes. Other newspapers supported Hughes. The Davenport Morning Democrat noted that "he faces the facts realistically" and "has shown the kind of courage and clarity of thinking as a candidate that would make him a good governor." 34

Beneath the editorials and headlines, Hughes appeared to be making inroads, even among those who disagreed with him. Harry Beardsley of West Des Moines wrote in a letter to the editor in the Des Moines Register that even though he opposed liquor by the drink, "I respect Harold Hughes for the intelligence and integrity he has shown in trying to think honestly about the liquor problem, and for his willingness to state clearly, unequivocally and forthrightly what he believes should be done about it." The final opinion poll issued by the Des Moines Register the weekend before the election showed Hughes behind but gaining. Erbe had a narrowing 52-48 percent lead among those already decided; the two were tied among city voters, 46-46, with Erbe showing a lead among "town" and "farm" voters. ${ }^{35}$

The result on election day-November 6, 1962-was a solid victory for Hughes over Erbe, 430,899 to 388,602. In the lightest voter turnout since 1946, Hughes cruised to victory by carrying Iowa's population centers, including Polk County, by more than 23,000 votes, accounting for more than half his victory margin. Among the five counties with populations above 100,000, Hughes carried all but one (Scott County) and won seven of the top 10 counties and 14 of the top 20. The victory was personal for Hughes; all the other statewide elected officers were Republican, prompting Des Moines Register editorial cartoonist Frank Miller to draw a state banquet table with a large donkey, grinning broadly at the center, surrounded by smaller, grumpy, and irritated elephants. ${ }^{36}$

34. Des Moines Register, 10/28/1962; Davenport Morning Democrat, 10/31/1962. 35. Des Moines Register, 10/22/1962, 11/4/1962.

36. Iowa Official Register, 1962-1963, 4; Des Moines Register, 11/7/1962, 11/8/ 1962. 


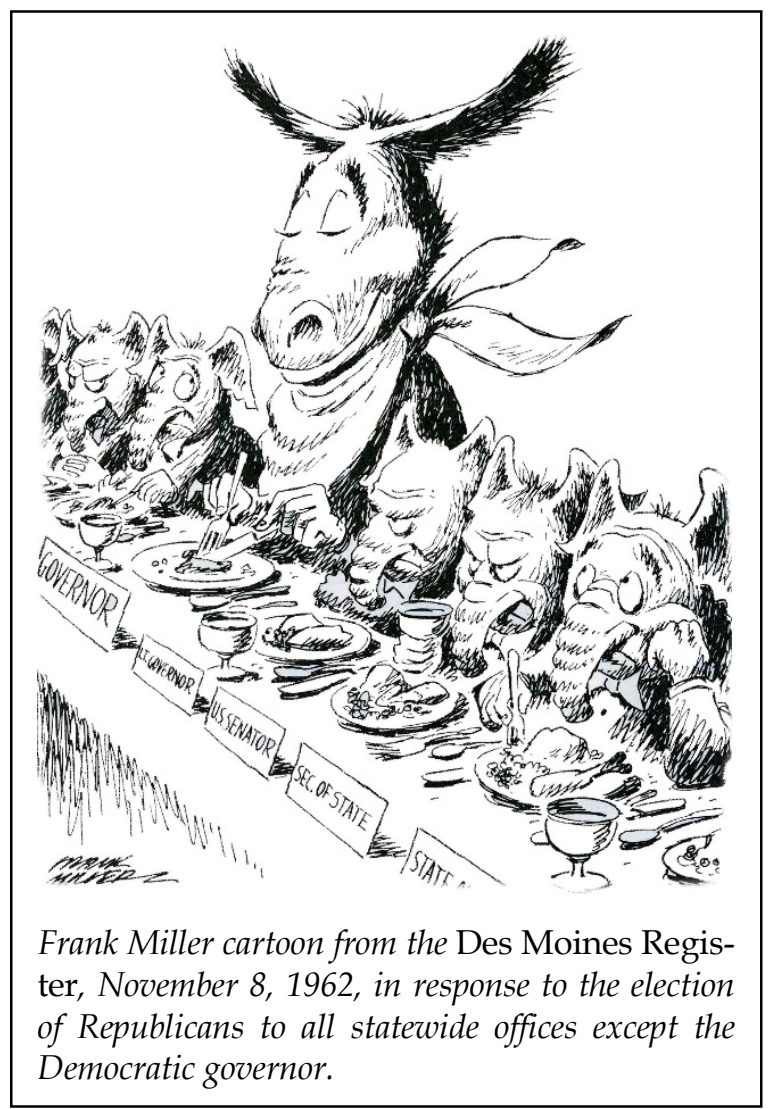

The banner headline in the Cedar Rapids Gazette after the election was "Hughes - Liquor Mandate." That immediate judgment may have been too simplistic, however. If some assumed that voters in border counties wanted liquor by the drink because they were next to states that had it, the evidence is not there. Only 9 of the 36 border counties and only 12 of the 19 river counties (next to the Missouri and Mississippi rivers) gave Hughes a plurality. One commentator, Frank Nye of the Cedar Rapids Gazette, wrote that many in the river cities did not want legalized liquor by the drink "since this would mean operators now paying no license fee would have to do so under almost any kind of legalizing act passed by the legislature." Many, including Hughes, said that he won the election because he took a strong stand on issues - certainly on liquor, but also on property 
tax relief, the need for capital improvements and other concerns. "We won because we had a program," said Hughes, "and because a majority of the voters believe that we had every intention of putting this program into effect, if elected." He added, "The liquor issue was to our campaign what a tail is to a dog. The tail is an important part of the dog, but the tail does not wag the dog - it is the other way around." 37

Another important factor in Hughes's win was a strong Democratic organization, especially in urban areas. Democratic State Chairman Lex Hawkins, a young, energetic Des Moines attorney elected in 1962, helped build the party, especially in the more populous counties, and improved the party's finances to get out the vote. In Polk County alone, Democrats moved from matching Republicans in party registration to having a 7,000 voter lead in 1962. Democratic Party workers in the larger counties were seen out at 6 a.m., getting supporters to the polls. Also, by the early 1960s the Iowa Democratic Party had cemented an expanding political relationship with organized labor that brought more working class voters to the party; in 1962, Democrats worked with labor leaders close to the election to register union members in 16 Iowa cities and get them to the polls on election day. In the other campaign, Erbe ran a lackluster effort, refusing to take a solid position on liquor by the drink and other significant issues, earning the wrath of Hughes's rhetoric and giving potential supporters few reasons to enthusiastically back the incumbent. Nevertheless, the consensus among state opinion makers was that Hughes's election had shifted the liquor-bythe-drink debate by placing in the governor's chair a strong, forceful proponent. ${ }^{38}$

37. Cedar Rapids Gazette, 11/7/1962, 11/11/1962, 1/5/1963; Des Moines Register, $12 / 16 / 1962$. One question is whether some Iowans voted for Hughes because he pledged to enforce current laws, not because he supported liquor-by-thedrink reform. That may have been the case for some, but that is difficult to determine. The fact is, however, that Hughes was very clear about aggressively pushing for liquor-by-the-drink reform, not for keeping the legal status quo. If there were voters who thought Hughes stood only for clamping down on liquor violators, they were getting only half his message on this issue.

38. Larew, A Party Reborn, 90; Des Moines Tribune, 11/7/1962; Davenport Morning Democrat, 11/8/1962; Des Moines Register, 7/29/1962, 11/7/1962; 11/10/ 1962; Sioux City Journal, 11/12/1963. By this time, many Iowa labor union leaders turned to the Democratic Party to pass legislative reapportionment, 
THE NEW DEMOCRATIC GOVERNOR, however, faced a Republican-dominated Iowa legislature that - at least on the surface-looked like it would present a significant challenge to passing a liquor-by-the-drink law. At the same time as they elected Hughes as governor, Iowa voters gave the GOP 78 of 108 Iowa House seats - all elected in 1962-and 19 of the 27 Senate seats at stake, giving Republicans a 38-12 Senate majority. Most political commentators believed that the liquor legislation would be much tougher to pass in the House, with its overwhelmingly rural makeup, than in the Senate. Some, such as the Sioux City Journal, doubted that much could be done from the governor's chair. "As governor, Mr. Hughes will be unable to push any legislation through the legislature, including his promise of liquor-by-thedrink for Iowa. This always has been a legislative decision. No governor can do much about it, even if he so desires." In midJanuary 1963 Des Moines Register reporter Nick Kotz estimated that the Senate had a majority ready to pass liquor by the drink, but the House, at that time, was about ten votes short of passage. Former Speaker of the House Henry C. Nelson (R-Forest City), who was not a candidate for the office in 1963, came out strongly against liquor by the drink, saying that "just because there are widespread violations of the present law" is not an argument for legalization. Comparing it to speeding on the highways, he said, "There are many violations of those laws also." 39

But attitudes were starting to change, even before the legislature met in January 1963. The most significant shifts were in

hoping to make the General Assembly more representative of urban populations and to repeal the state's right-to-work law. They simply had no confidence in achieving those goals through the Iowa Republican Party with its strong links to business through the Iowa Manufacturers Association (IMA). The 1956 merger of the AFL-CIO created a more politically unified labor movement at both the state and local levels and was a factor in Democrat Herschel Loveless's Iowa gubernatorial wins in 1956 and 1958. Growing labor support certainly helped Hughes in 1962 in such counties with strong union populations as Black Hawk (home of John Deere and Rath Packing) and Wapello (home of John Morrell and Company). See Wilson J. Warren, Struggling with "Iowa's Pride": Labor Relations, Unionism, and Politics in the Rural Midwest Since 1877 (Iowa City, 2000), esp. chap. 6, "Local 1's Unionism and the Transformation of Iowa's Politics, 1939-1970," pp. 85-102 (reprinted in this issue).

39. Des Moines Register, 11/10/1962, 11/11/1962, 12/7/1963, 1/10/1963, 1/15/ 1963, 1/20/1963. 
the Iowa Republican Party itself. In a secret poll taken for the Republican Party in the fall of 1962 by Central Survey, Inc., of Shenandoah, 63 percent of Iowans favored liquor sales, with only 30 percent opposed; even Republicans favored it 49 percent to 45 percent. Facing such stark numbers, on December 10, 1962, Republican Party State Chairman George Nagle of Iowa City publicly endorsed passage of liquor-by-the-drink legislation and convinced the Republican State Central Committee to also support the effort, although the vote was not unanimous. Nagle realized that opposition to this reform was becoming an albatross around the neck of the Iowa GOP, and he wanted it removed as soon as possible. That attitude was becoming widely shared throughout the state party. In a survey conducted by the Iowa Daily Press Association among Iowa Republican Party chairmen and vice-chairmen in early 1963, 60 percent of the 75 leaders contacted favored liquor by the drink, as long as it had stringent enforcement provisions. One respondent was quoted as saying, "Don't repudiate city Republicans or our party is dead." Even the leader of the Republicans in the fall campaignGovernor Norman Erbe-had a change of heart and threw his support to the effort. In a newspaper interview after the election, Erbe said that he "personally felt there should be some liquorby-the-drink system in Iowa" and, if he had to do it over again, he would have supported reform. He said he had refrained from doing so in the campaign because felt bound by the GOP platform, which only called for review of liquor laws. ${ }^{40}$

Newspapers around the state, taking the election of Hughes as an indication that Iowans wanted liquor by the drink legalized, supported change-as well as Hughes's pledge to enforce current law until it was changed. The Burlington Hawkeye wrote, "A principal reason Iowa has never become serious about changing its laws is that most areas already have liquor by the drink, so why stir it up? If most areas suddenly do not have liquor by the drink, the demand for a legislative change could well be so loud it will even penetrate the dense ears of the legislators." Others noted that increased state revenue would accompany legalization and that this was changing the minds of many "drys."

40. Des Moines Register, 12/11/1962; Des Moines Tribune, 11/10/1963; Cedar Rapids Gazette, 12/20/1962, 1/24/1963, 2/4/1963; Sioux City Journal, 11/8/1962. 
According to the Davenport Morning Democrat, "Many who do not favor liquor itself under any circumstance have nevertheless been won over to the idea [that] since we actually have liquor by the drink in much of Iowa, the state should be collecting revenue from it." 41

THE MAN at the center of the effort immediately showed that he meant what he said in the campaign about enforcing current law. At a victory celebration in mid-November in Ida Grove, Hughes declared, "I hope illegal sale of liquor comes to a stop before I become governor. It will make things simpler for everybody if that happens." During a press conference in Des Moines in early December, Hughes called on sheriffs and county attorneys to start enforcing the law on liquor. If they did that, he said, it would not be necessary to use state officers for that purpose after his inauguration on January 17, 1963. In a meeting with legislative Democrats the same day, he met some opposition to strict enforcement, but he made it clear that he was not changing his mind: "They might as well go home and make peace with their constituents." The strategy - and the gamble that Hughes was taking-was to make legislators see that the current liquor law, when enforced, was unpopular, thus putting pressure on them to change it. ${ }^{2}$

Others in state government began altering their tone. Formerly lukewarm about liquor law enforcement during his first term, Iowa Attorney General Evan Hultman, a recently reelected Republican, addressed county attorneys on November 16 in Cedar Rapids and urged them to cooperate with Hughes if he sought to enforce the liquor laws. Hultman said that he was prepared to give his support and hoped the county attorneys would do so as well. Later in November Hultman announced that he was forming a 15-member state crime council, composed of state and local officials, to work out uniform enforcement of Iowa's present liquor laws and other statewide crime problems.

41. Burlington Hawkeye editorial reprinted in Des Moines Register, 11/24/1962; Davenport Morning Democrat, 11/28/1962.

42. Des Moines Register, 11/18/1962, 12/4/1962; Davenport Morning Democrat, $12 / 4 / 1962$. 
The prime focus, he said, was enforcing the state's liquor-bythe-drink laws. ${ }^{43}$

On December 10, Iowa Safety Commissioner Carl Pesch, anticipating an order from Hughes to crack down on illegal liquor traffic, announced that he was ordering 27 state agents into training. The agents included 17 from the State Bureau of Criminal Investigation and 10 from the auto dealer, license, and motor vehicle registration division who would be diverted from their primary duties to enforcing liquor laws. Creating what he called "liquor law schools," Pesch said the agents in the State Department of Public Safety would receive refresher courses in raiding techniques, search and seizure, preservation of evidence, and other subjects related to liquor law enforcement. He said he was "certainly aware that new and novel responsibilities soon may be thrust upon this department," adding that this could force "a drastic and irreversible change in the philosophy and mechanics of all law enforcement in Iowa." This was not his preference, he noted, but "my personal opinion is not pertinent." 44

Hughes made the effort official on January 3 when he appeared at a Des Moines press conference with Pesch to announce a statewide crackdown on illegal liquor sales. The Des Moines Register headlined the story, "Hughes Set to 'Dry Up' Iowa." The governor-elect said that he hoped he would not have to use state forces; he would prefer that local law enforcement bodies make sure that businesses complied with current law. "I believe that adequate warning has been given that I expected voluntary enforcement before taking office," he said. "And we are not going to wait two months and see what the legislature will do with the liquor laws." 45

The effect was immediate around the state. According to an investigation by the Des Moines Register, many tavern and club operators, especially in the river cities, voluntarily stopped selling liquor by the drink, fearful of prosecution by either local or state officials. Linn County Attorney Jack Fulton reported, "I understand that it has been very difficult to buy a drink in Cedar

43. Cedar Rapids Gazette, 11/17/1962; Sioux City Journal, 11/28/1962.

44. Cedar Rapids Gazette, 12/11/1962.

45. Des Moines Register, 1/4/1963. 
Rapids and Linn County." Tamiel Bleyart, a Davenport tavern operator who said he spoke for others in his business, said that most operators had agreed to "call things to a halt" before Hughes took office. Requests for a mixed drink at Council Bluffs water places drew a "sorry, no more" from the bartender. Louis Meyer, president of the Dubuque Tavern Keepers Association, claimed that the loss of over-the-counter liquor sales would put about 200 people out of work in the county. ${ }^{46}$

For the most part, the "drying" of Iowa came through voluntary action or from warnings by local law enforcement. In Fort Madison, tavern owners were called to City Hall and advised that "if they had illegal liquor to get rid of it," said Police Chief Richard Peak, who called the town "drier than a bone." Muscatine Police Chief Clifford Bennett reported that "almost all of the liquor is gone from Muscatine and all of it will be gone when Hughes becomes governor"; he said he had made it known that the laws would be enforced and that plain-clothes police officers would make periodic liquor checks. In Clinton most taverns stopped serving liquor in early January, said Police Chief M. H. Etherton, who added that two liquor raids at that time "gave some impetus" to the dry-up. Davenport's tavern owners reached a "gentlemen's agreement," informally binding them to serve the last shot of liquor the evening of Saturday, January 13; the agreement was preceded by a wellpublicized promise by the Scott County attorney and sheriff to fully cooperate with state authorities to shut down the illegal liquor trade there. ${ }^{47}$

One clear sign that the change was real came with a drop in sales at the state liquor stores in traditionally "wet" counties on Iowa's eastern and western borders. Merchants selling illegal liquor by the drink had purchased some product from Iowa state stores-despite statistics from the Hughes campaign showing that some alcohol came from outside the state-and, when that stopped, sales fell. Purchases at state stores for January 5-11 in Davenport, Dubuque, Bettendorf, and Council Bluffs

46. Des Moines Register, 1/13/1963; Cedar Rapids Gazette, 1/7/1963, 1/8/1963.

47. Des Moines Register, 1/13/1963; Davenport Morning Democrat, 1/6/1963, $1 / 11 / 1963$. The Scott County agreement soon proved to be less binding than promised. 
were estimated at 50 percent below the same week a year earlier. In Sioux City, Fort Dodge, and Carroll, sales were down by several thousand dollars compared to a year earlier. Sales were about the same or off only slightly in major stores in Cedar Rapids, Waterloo, and Des Moines. "There is little doubt that the sales falloff is a result of Governor-elect Harold Hughes's warning that illegal liquor sales must stop," said Homer Adcock, who chaired the Iowa Liquor Control Commission. A week later, the commission reported that statewide liquor sales had fallen $\$ 85,000$ from the previous year and, the next week, had plunged $\$ 100,000.48$

Most merchants voluntarily ended over-the-counter liquor sales, but they did not see this as a permanent condition. Most accepted the halt of liquor sales as temporary, seeing it as putting pressure on the legislature to change the law. Some said that the pause would last only until state agents demonstrated their course of action or lack of action. Ben Thomas, president of the Tavern Owners Association in Clinton, commented, "How long it will last, I don't know. The dry-up is to show Hughes we are willing to co-operate. We want liquor by the drink." "I'm interested in seeing what's going to happen if the legislature ditches liquor by the drink," said Carroll County Attorney Robert Bruner. "I personally think this will last as long as the governor maintains his stiff attitude." 49

One reason many saw this as temporary is that merchants could not sustain the serious income losses they were suffering. "Our loss will be tremendous," reported Robert Rosenthal, manager of Cedar Rapids Elks Lodge 251, which had removed all liquor from its bar. The owner of a leading bar in Sioux City said restaurant business had fallen sharply there and was going to South Sioux City, Nebraska. He added, "They think they've got a gold mine now." Some establishments in Sioux City closed because they simply could not do business. By early February in the western Iowa city, many bartenders and waitresses were laid off, and meat and food sales to restaurants were below normal. Sioux City Councilman Julian Torgerson said that 11

48. Des Moines Register 1/13/1963, 1/17/1963, 1/23/1963.

49. Des Moines Register 1/13/1963. 
conventions had either cancelled in Sioux City or moved across the river to South Sioux City. In Dubuque, city officials estimated that enforcement was costing the city a $\$ 1$ million drop in business, a $\$ 200,000$ loss in wages, and $\$ 40,000$ less in taxes for the city. The economic impact of enforcing the liquor-by-the-drink prohibition was real, significant, and affecting the lives of Iowans. In Davenport, Scott County Attorney Martin Lear said that by late January he had received no complaints of liquor being sold in bars - "not even any anonymous letters." According to one Davenport tavern owner, "Business is lousy. I couldn't sell enough beer to even pay my help." Some city tavern owners increased the price of draft beer from 15 to 20 cents simply to make ends meet. A number of Davenport taverns closed before midnight due to lack of business. ${ }^{50}$

After Hughes took office as governor on January 17, 1963, he formally launched his effort to clamp down on illegal liquor sales. After a week on the job, the governor met with Attorney General Hultman and, in a joint news conference, Hultman pledged his full support to Hughes in state enforcement of liquor laws. The attorney general said his role would be to give county attorneys a firm policy statement on liquor enforcement and handle relations with them on execution. ${ }^{51}$

By the end of January, according to a report submitted to Governor Hughes, state undercover agents had investigated 63 taverns and clubs throughout Iowa over seven days and found no liquor for sale by the drink. Nevertheless, some still had not gotten the word, and the governor's office was working behind the scenes to stamp out violations. Hughes and his aides received several communications from Iowans, alerting them to operators still selling illegal liquor. Dwight Jensen, executive assistant to Hughes, received an unsigned letter on February 4, stating, "A good time to check on Phillis Tavern on Locust Street in Carter Lake, Iowa would be next Tuesday." Jensen passed the letter on to Carl Pesch. On the same day, Jensen sent another letter to Pesch, describing a phone call he had received

50. Des Moines Register, 2/10/1963, 2/28/1963; Cedar Rapids Gazette, 1/25/1963; Davenport Morning Democrat, 1/15/1963, 1/25/1963.

51. Des Moines Register, 1/24/1963. 
from Elma Deacon of Bernard, Iowa, on sales at the Laverne Klocker establishment: "Mrs. Deacon reports the following: They are still selling liquor there. It has not stopped one bit. They have minors behind the bar serving liquor. Sometimes they don't close until 1:30 on Sunday mornings. And, they have poker games every Saturday night. They keep liquor in a tool shed right outside the door and I think it's time something is done about it." Jensen added, "Would you please have this investigated?" 52

Hughes himself contributed to this surreptitious assistance to law enforcement. In mid-February the governor related to Pesch a conversation he had had with Cresco Mayor Frank Church discussing a "liquor control problem in this town that he cannot solve and asked assistance from State Agents." The mayor told Hughes that "local authorities are thwarted by political strife between county and city officials." "He added that his visit to Des Moines was known by several people in the town. For these reasons, he advises waiting about three weeks before sending a man in." Hughes also conveyed to Pesch correspondence he had received from a source on the Midwest Tavern in Davenport: "My informant says that the best time to investigate this situation is around 3:00 p.m. on Friday afternoon." Later, the governor wrote to Pesch, "We have received information that Davenport is far from dry. The source of our information says that Davenport is $90 \%$ open on liquor, that bartenders are mixing drinks in Coke and 7-Up bottles and pouring liquor from pitchers kept under the bar, and that he would like to see some action." Still other letters from Hughes mentioned violations in Remsen, Merrill, and Hilton. 53

The administration turned its words to action on both sides of the state beginning the evening of February 28. In Davenport, three state agents, together with local police, raided the Tiptopper Tavern, arresting owner Chester Bowes, confiscating 18 bottles of liquor and charging Bowes with possessing liquor on premises with a beer permit. The state agents had checked 15

52. Des Moines Register, 1/31/1963; Letters, 2/4/1963, Liquor Control Commission, 1963-1964, 1967, box 9, HEH Papers.

53. Hughes to Pesch, 2/12/1963, 2/19/1963, 2/20/1963, Liquor Control Commission, 1963-1964, 1967, box 9, HEH Papers. 
taverns and clubs in Davenport that day and raided the Tiptopper Tavern after they were able to purchase liquor there. Early in the morning of March 1, 35 officers (six state agents, six local regular and six special deputies, as well as sheriffs and other deputies from other counties) armed with a dozen shotguns raided the Shangri La Club owned by Leo Kublik at Carter Lake on the Nebraska/Iowa border north of Council Bluffs. In all, 127 bottles were seized at the club and another 48 were found in a car in the driveway. Several days later, in an action that was the result of undercover work by state agents, police raided the Chateau Club in Clinton, arresting owner Peter Rankins of Camanche and confiscating 19 bottles of liquor. Raids continued in other areas of the state. ${ }^{54}$

Davenport's over-the-counter liquor merchants proved to be more resilient than others in the state and received continued close attention from state agents. Another series of raids was planned in Davenport for Saturday evening, March 30, after state agents had either bought illegal liquor or watched it being sold in six Davenport establishments. The raids were called off after an agent overheard a barmaid in one tavern telling a customer every detail of the plan, including the places to be raided, the exact times, and where the agents were to gather before staging the raids. Davenport law enforcement officials were blamed for the leak, creating some tension between them and state agents. Several days later, Hughes himself mentioned the cancelled raids in a Des Moines news conference, referring only to "a border city" and indicating that state agents might operate

54. Davenport Morning Democrat, 3/1/1963, 3/13/1963; Council Bluffs Nonpareil, $3 / 7 / 1963,3 / 20 / 1963,3 / 29 / 1963$. One interesting legal technicality that played itself out in the Carter Lake raid concerned the car containing full liquor bottles in the trunk. Carter Lake holds the peculiarity of being the only Iowa town west of the Missouri River, due to flooding that redirected the river to the town's southeast in 1877. At the time of the raid, the car, registered under the name of the club owner's wife, was parked near the Nebraska/Iowa border. Club owner Leo Kublik claimed that Iowa authorities had no jurisdiction over the car, since it was parked out of state at the time-or so he claimed. Authorities photographed the car's location and did a survey to determine the exact border line between the two states. The photo and survey showed that the trunk of the car edged into Nebraska with the front of the car in Iowa, so the district judge disqualified the liquor in the truck as evidence. Kublik, however, was convicted of illegal possession of alcoholic beverages within a beer tavern at a later trial, based on the liquor found in his club. 
there in the future with minimal local involvement. That was the policy when six state agents simultaneously raided two downtown Davenport taverns on the evening of Wednesday, May 1, without the knowledge or assistance of the Davenport police, seizing four bottles and a glass at one place and three bottles and a glass at the other. ${ }^{55}$

Hughes was well aware that the statewide crackdown was putting a strain on Iowa law enforcement. At the end of March, he acknowledged that other law enforcement efforts were suffering because state agents were assigned to liquor enforcement. "If these agents are devoting their time to liquor law enforcement, they cannot take part in investigations of murders, robberies, burglaries and other crimes. But until present liquor laws are changed, they must be enforced." The message was clear to legislators meeting in Des Moines: pass liquor-by-the-drink reform or face the dire consequences of hampered law enforcement - to say nothing of the negative economic impact suffered by many merchants. ${ }^{56}$

A MINIMUM of 55 votes was needed for passage in the 108member Iowa House. One legislator who was a longtime advocate of liquor by the drink said in mid-January that he could count only 41 House members likely to support such legislation. Assistant House Majority Leader John Camp (R-Brant) counted 35 "drys," 40 "wets," and 33 undecideds. Camp believed that seven or eight among the undecided would vote for a "good bill if convinced there are enough votes to pass it"; another two or three would vote for a bill containing a provision for compulsory testing of persons arrested for driving while intoxicated, leaving 50 to 52 votes for a possible liquor-by-the-drink bill, just shy of a majority. At the beginning of the 1963 legislature, supporters of liquor by the drink had work to do. ${ }^{57}$

The divide between "wets" and "drys" was not partisan; it was an urban/rural issue, with members of each camp in both

55. Davenport Morning Democrat, 4/4/1963, 5/2/1963.

56. Des Moines Register, 3/30/1963.

57. Des Moines Register, 5/13/1962, 1/13/1963, 5/17/1963; Cedar Rapids Gazette, 1/15/1963, 1/20/1963. 
parties. Democrats, led by Hughes, were for the most part on the side of change, though there were a few opponents within the party. The great battle was among the Republicans. Party leaders, such as George Nagle and Norman Erbe (after his change of heart), were on the side of reform. Given that the Republican platform in 1962 called for a "re-evaluation" of liquor laws, the Republican leadership in the legislature felt obligated to fully debate liquor by the drink in both chambers and not hold it up in committee. Some in the GOP privately argued that they could not afford to give Hughes a political victory by supporting and passing his liquor pledge; others, like Nagle, countered by warning that, if they did not pass liquor by the drink, Hughes would again carry the issue to the public in 1964 - with possibly disastrous results for Republicans. ${ }^{58}$

Rural Republicans were also uneasy about another 1963 political issue - the Shaff Plan for legislative reapportionmentthat could be linked to the liquor issue. The Shaff Plan, drawn up by the Iowa Farm Bureau Federation and named after Republican State Senator David Shaff of Clinton, called for a 99member House with one representative from each county and a Senate based on population. This was a compromise put forth by rural interests to deflect comprehensive change to a legislature based entirely on population. The plan had passed as a constitutional amendment in the 1961 session of the legislature and would pass again in 1963; the proposal would go before the people in December 1963. Some Shaff supporters feared that, if liquor by the drink failed in the 1963 session, urban interests would blame the rural bias in the current General Assembly and reject the Shaff Plan at the polls. This caused some rural politicians to reconsider their longtime opposition to liquor by the drink. Another impact of the Shaff Plan was that it could potentially set up a House controlled by 24 percent or less of the Iowa population, creating a strong rural block to a liquor bill in future legislative sessions; this prompted liquor-by-the-drink supporters to push aggressively for reform in 1963 or risk losing a chance for years. 59

58. Larew, A Party Reborn, 85; Des Moines Register, 1/10/1963, 1/20/1963.

59. Wiggins, "Reapportionment Battle," 408; Cedar Rapids Gazette, 3/3/1963. Despite the passage of liquor-by-the-drink reform, the Shaff Plan went down 


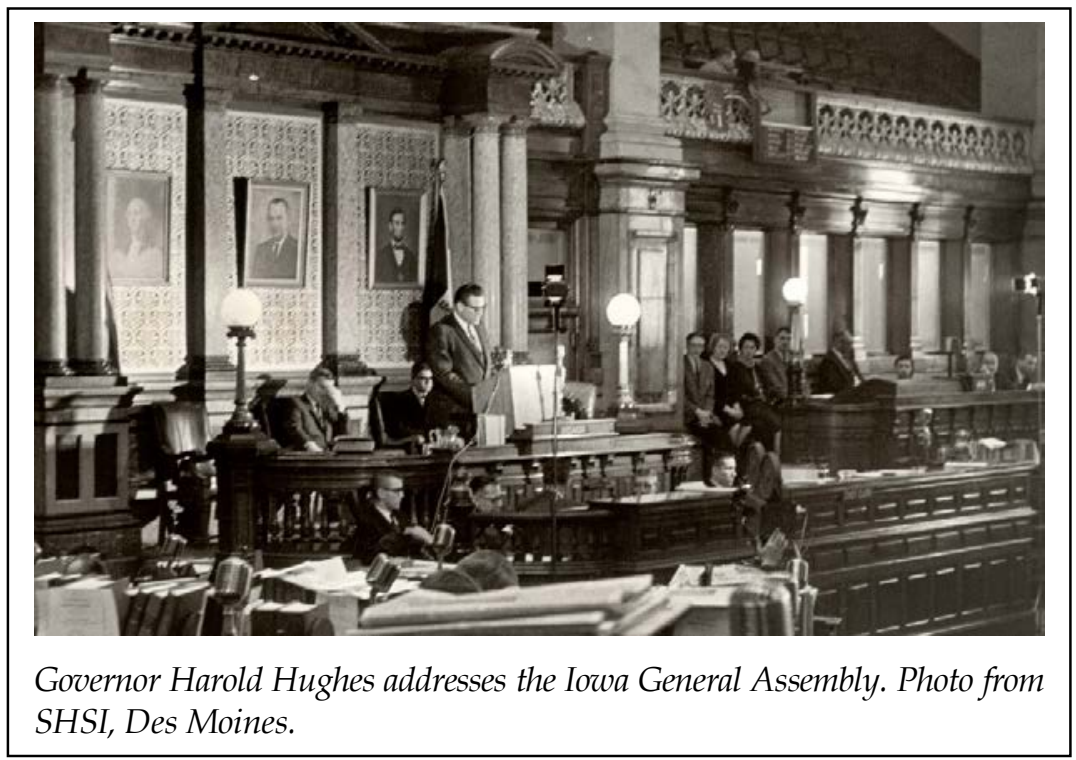

The legislative strategy of Hughes and the Democrats was to avoid introducing liquor legislation that could be labeled a "Democratic bill," destined for probable defeat in the Republicandominated General Assembly. Instead, they decided to participate in a bipartisan effort. Supporters believed that efforts should begin in the Senate, where it had the best chance of passage. Thus, in mid-January, legislation was taken up by the Senate Judiciary II Committee. (This was one of two Senate Judiciary Committees, and it was responsible for liquor legislation.) The committee was chaired by Senator Jack Schroeder, Republican from Davenport and an ardent backer of liquor by the drink. Schroeder, 38 years old and vice president/general counsel of General Life of Iowa, had extensive contacts in both chambers; he had served several terms in both the Iowa House and Senate

to defeat anyway, 191,421-271,217, in the December 3, 1963, vote. One factor was Hughes's campaign against the measure. See Larew, A Party Reborn, 86. Iowans then lived through a series of court battles and political debates, complicated by the U.S. Supreme Court decision, Reynolds v. Sims in 1964, which ruled that legislative chambers must be apportioned on population, one-person, one-vote, until the issue was settled. 
and was the former Republican majority leader. It was well known that his committee had a solid "wet" majority. 60

Legislators began their committee work against the backdrop of statewide and local enforcement of current liquor laws, resulting in the "drying of Iowa" and intense statewide lobbying for and against liquor by the drink. At first, it appeared that opponents held the upper hand. On January 21 alone, five petitions opposing liquor by the drink were filed in the House with only one in favor. Tom Riley, one of the two representatives from Linn County, the second most populous county in the state, said that he had received 100 letters against a liquor bill and only one in favor; John Ely, Linn County's other representative, had received 22 letters against a bill and only one phone call in favor. ${ }^{61}$

Much of the opposition was spearheaded by church leaders, particularly the powerful Methodist church, with about 290,000 members throughout Iowa. Methodist Bishop R. Gerald Ensley of Des Moines had already issued a statement in December 1962 opposing liquor by the drink, saying that it would increase alcoholism in Iowa and that every dollar collected in taxes would be offset by three to five dollars in expenses to combat "crime, poverty and marital misery." On January 4, the board of directors of the Iowa Council of Churches, representing 15 Protestant denominations with 2,600 local congregations and 700,000 members, declared its opposition to liquor by the drink. They were joined on January 20 by the executive committee of the Iowa Yearly Meeting of Friends, which issued a statement that liquor by the drink would increase consumption, resulting in loss of life on highways and more crime. In late February the Iowa Council of Churches conducted an all-day meeting at Wesley Methodist Church, a block north of the Iowa Capitol, to discuss its position, inviting legislators to dinner and urging local churches statewide to invite their legislators to attend. ${ }^{62}$

Religious opposition to liquor by the drink was not unanimous, however. Episcopal Bishop Gordon Smith, speaking for his church, which had 25,000 members in Iowa, said, "This is

60. Des Moines Register, 1/15/1963, 1/17/1963; Iowa Official Register, 1963-1964, 45.

61. Des Moines Register, 1/22/1963; Cedar Rapids Gazette, 1/22/1963.

62. Des Moines Register, 12/19/1962, 1/6/1963, 1/21/1963, 3/3/1963. 
not a moral issue with us at all but merely a question of the best way to control the use of alcohol. The present Iowa liquor laws have proven inadequate to properly control liquor and have produced attendant evils including the key club situation and a general disrespect for law and order. We should enact liquorby-the-drink legislation which can be enforced and accepted by the majority of our citizens as the proper way of handling the liquor problem." Speaking for Iowa's 435,000 Catholics, Bishop James J. Burnes observed that "nowhere in history has the Church condemned the moderate use of liquor." Citing respect for law and its enforcement, he called the existing liquor laws "bad legislation and therefore not law." Among religious leaders supporting change, the most direct was Rabbi Irving A. Weingar of Tifereth Israel Synagogue, Des Moines. "We have no objection to liquor. We never have a celebration without the use of wine. . . I personally believe that our present liquor laws are a farce. We are taking honest people and making them dishonest. If liquor is evil, then let's make an issue of liquor, not of liquor by the bottle or by the glass. Certainly people will violate liquorby-the-drink laws. But this would be better than what we have now - plain drinking without any control." 63

Opposition to liquor by the drink also stemmed from a nonreligious body. In a half-page ad appearing in the statewide Sunday Des Moines Register in March, the Preferred Risk Mutual Insurance Company of Des Moines, calling itself "America's Original Non-Drinkers Auto Insurance Company," issued a message to Iowans, "Is Liquor-by-the-Drink Worth 44 Lives?" Citing statistics from surrounding states, the ad argued, "If Iowa's highway death toll had been the same as liquor-by-thedrink neighbors, it would mean 44 more Iowans killed last year." It urged readers to call, telephone, or write legislators through card or letter to tell them to vote against liquor reform. The ad also offered readers a free report: "Will Legalizing Liquor-bythe-Drink Increase the Death Toll on Iowa's Highways?" 64

During a press conference in mid-January, against the backdrop of lobbying efforts by some religious groups and others,

63. Des Moines Register, 3/3/1963.

64. Ibid. (emphasis in original). 
Hughes urged "wets" to be more vocal in voicing their opinions to legislators. Legislators had told the governor that most of their mail was running against liquor by the drink and that much of it was organized by religious groups, primarily the Methodist church. One rural Democratic legislator told Hughes that he was personally in favor of reform but that he had received 300 letters against liquor law change and only one in favor. Hughes insisted that "persons who want the law changed must organize in conveying their feelings to legislators." 65

The governor was also beginning to play hardball with Democratic legislators. In a meeting at the Hotel Savery in Des Moines in late January with his party's legislative caucus, including an estimated eight "dry" Democrats, Hughes warned that failure to support liquor by the drink "may determine the amount of consideration their recommendations for appointments in state jobs may get." He added that he would "mobilize every man he can find to enforce the present law in the next two years, if the legislature does not act on the liquor issue." 66

One unexpected argument against liquor reform was that enforcement of current law was actually working, so no change was needed. A young Charles Grassley, then a state representative from New Hartford and a solid "dry," said, "The Hughes campaign is proof the law can be enforced and there is little need for a change." But the general feeling among most legislators was that enforcement was only temporary and could not continue, given the strains it placed on law enforcement and local economies; after the initial pressure, establishments would simply go back to selling liquor. As Representative Scott Swisher (D-Iowa City) said, "There are not enough law enforcement officers in the state to override the wishes of the people." 67

Hughes's call for petitions and, no doubt, a response to state and local enforcement began to bear fruit by early February. An unofficial tally of petitions received in the Iowa House showed 60,000 names in favor of liquor by the drink and 4,000 against.

65. Des Moines Register, 1/20/1963.

66. Des Moines Register, 1/29/1963.

67. Des Moines Register, 1/24/1963. 
By February 21, nearly 100,000 Iowans had petitioned legislators in favor, with only 6,031 against. Representative Riley Dietz (RWalcott), who was tracking the petition numbers, said, "In several instances, legislators have received more signatures favoring liquor by the drink than they did votes in last November's election." One representative, after receiving another packet of petitions favoring liquor by the drink, said, "I thought my county was dry." In addition to petitions, legislators were being overwhelmed by letters from voters. George Mills of the Des Moines Register called it the "biggest mail session of modern times." 68

By mid-February, Governor Hughes was regularly meeting with a bipartisan group of legislators from both houses, including Schroeder of Davenport and the Senate and House majority leaders, to see how votes were lining up on the liquor issue and to discuss the shape of legislation. The numbers were looking good, though specific legislation had not yet been drawn up. The Des Moines Register reported on February 20 that a survey of House members showed 58 representatives -36 Republicans and 22 Democrats - backed general liquor-by-the-drink legislation, surpassing the 55 votes needed for passage. ${ }^{69}$

Senator Schroeder, leading the legislative writing of the bill and guiding it through the Senate, refused to accept any deals or "horse trading" to get liquor by the drink passed. "If legislators - after receiving the petitions they have received for legalizing liquor and after the polls indicating the vast majority of Iowans are in favor of changing the present laws - aren't willing to vote for a measure on its merits then certainly I'm not going to be willing to trade or exert any undue pressure to get a liquor bill passed." He saw passage of the liquor reform effort as nothing less than the preservation of the Iowa Republican Party. "My own feeling is that the future of the Republican party in Iowa is at stake and that changing the liquor laws could be its redemption. If, as the majority party in Iowa, we Republicans don't accede to the wishes of a majority of the people, then sooner or later we'll become the minority party." 70

68. Des Moines Register, 2/11/1963; Cedar Rapids Gazette, 2/21/1963.

69. Des Moines Register, 2/12/1963, 2/20/1963.

70. Cedar Rapids Gazette, 2/24/1963. 
In a further effort to counter pressure from church groups against liquor reform, Democratic and Republican legislative supporters met with business leaders at the Wakonda Country Club in Des Moines in late February - just ahead of a weeklong midterm recess when legislators would be talking with voters. At this strategy session, participants urged the business people to apply pressure to House members considered "marginal" on the liquor issue. Senate Majority Leader Robert Rigler (R-New Hampton), one of the leaders of the gathering, said, "It would be very helpful if business groups such as Chambers of Commerce and commercial clubs take a stand and let their legislators know how they feel about liquor by the drink" and "how the business men back home felt about it." Robert Tyson, executive secretary of the Republican state central committee, announced on March 1 that he and other Republicans would fan out across the state during the legislative recess to gain additional support for liquor by the drink. ${ }^{71}$

As the issue continued to drag on into late March without action, Hughes applied public pressure to legislators. In a speech at a six-county Democratic dinner in Perry that was publicized statewide in a press release, the governor said, "It would be disastrous if they wait much longer." He called on legislative leaders to "start taking action - and soon - on a sensible liquor control bill." Repeating his earlier arguments that "we will soon see this state drift into an atmosphere of cynicism where there will be little respect for any law," he said that his enforcement efforts since January did not "mean we have made Iowa 'dry' or halted the intemperate use of alcohol. It only means we have driven bootlegging in this state further underground. Make no mistake about it. If the people of Iowa do not wish Iowa to be dry, a few state police agents cannot make it dry." Tossing aside the arguments of some "drys" that enforcement could work in the long run, he said that it was temporary at best and liquorby-the-drink reform was the only alternative to lawlessness. ${ }^{72}$

71. Cedar Rapids Gazette, 3/1/1963.

72. "Press release on address to six-county Democratic dinner in Perry, March 27, 1963," Press Releases 1963, box 25, HEH Papers. 
PROPOSED LEGISLATION finally emerged from the Senate Judiciary II Committee on Wednesday, April 4, on a 7-0 committee vote. The only token opposition came from Senator Jacob Grimstead (R-Lake Mills), a committed "dry" who still spoke with a Norwegian accent. By voting "present," according to the Cedar Rapids Gazette, he "yielded to the growing demand for legalized glass liquor sales." (Schroeder told Grimstead at the vote, "Jake, you've come a long way.") The committee bill called for a 10 percent tax on gross receipts from the sale of alcoholic beverages and set up licenses with different fee levels among four classes: clubs, hotels/motels, commercial establishments with tables and seats for at least 25 people, and airlines and railroads. The bill set hour limits on liquor sales. City and town councils and county boards of supervisors would have final approval on whether liquor licenses would be issued. There was no provision in the bill for a "local option" vote to prohibit sales within counties or towns. After reading the proposed bill, Governor Hughes objected to a clause limiting liquor sales to only within business districts, which would prevent neighborhood taverns from participating, and he said that he would prefer that enforcement powers be under the Liquor Commission rather than the Bureau of Criminal Investigation. But that was only the beginning of the negotiating process. ${ }^{73}$

The bill's supporters waited a week before bringing the legislation to the Senate floor. Hoping to get a jump on opponents and avoid an avalanche of phone calls to wavering legislators, on Wednesday, April 10, at 9:37 a.m. they suddenly announced that they would begin debate. Senators Schroeder and David O. Shaff led the floor fight for the bill and thwarted most attempts to amend it. Opponents-led by Senators Eugene M. Hill (DNewton), a farmer, and John A. Walker (R-Williams), a banker and farmer - made several attempts to increase license fees, but these were rejected. "If we get the cost too prohibitive," argued Schroeder, "it will give incentive to circumvention through bootlegging." 74

73. Cedar Rapids Gazette, 4/4/1963, 4/5/1963; Des Moines Register, 4/4/1963.

74. Cedar Rapids Gazette, 4/11/1963; Des Moines Register, 4/11/1963. 
One turning point in the debate came with the effort to include "implied consent" in the bill; this meant that, when a citizen signed his or her driver's license, it implied that the person had given consent for chemical tests of breath or body fluid for alcohol content if suspected of drunken driving. Presiding over the Senate, Lieutenant Governor William Moody ruled the provision out of order because it was contained in legislation currently being debated in the House. Without the "implied consent" clause in the proposed legislation, some Senate supporters considered changing their vote to "no," throwing the bill's passage into doubt. 75

As the debate lingered on that day, it was obvious that supporters did not yet have the votes to pass the legislation, so they stalled with unplanned speeches and questions while applying pressure to undecided senators. The battle was for the votes of three individuals - Leigh Curran of Mason City, Donald Beneke of Laurens, and Irving Long of Manchester, all Republicans. "At midmorning, we had 26 or 27 votes [26 were needed for passage]," said one senator supporting liquor by the drink, "but as the radio announced over Iowa that the debate was on, the pressure started pouring into this chamber." This included calls from ministers and other opponents throughout Iowa; they came in person, calling senators off the floor to lobby, and flooded the Senate's telephone switchboard. At late afternoon, Mason City's Curran was at the center of the pressure tactics, receiving calls, pro and con, from his home county and taking part in hushed discussions in the Senate cloakrooms, aisles, and hallways. Finally, at 4:41 p.m., talk suddenly stopped in the chamber for the first time that day and Senate Secretary Carroll Lane's voice started reading the roll call in alphabetical order. When Leigh Curran voted "Aye," an anonymous voice from the floor cried, "That does it!" When the roll call was finished, the Iowa Senate had passed its liquor-by-the-drink bill, 26-24. ${ }^{76}$

The final Senate vote divided both political parties. Seventeen Republicans and 9 Democrats voted yes; 21 Republicans and 3 Democrats voted no. In addition to Curran, two other known 
"drys" voted for the bill: Charles Van Eaton (R-Sioux City) and George O'Malley (D-Des Moines). "I'm against liquor in any form," said Van Eaton after the vote. "I am also a practical individual. I've seen attempts to enforce the present liquor law and it can't be enforced. The whole question is this: Are you going to have liquor by the drink in Iowa legal or illegal?" Cedar Rapids Gazette reporter Frank Nye added up the county populations represented by the senators voting for and against the bill, coming up with a total of $1,829,362$ to 928,175 . "This vote pretty well bears out the polls which indicated that about two-thirds of Iowa's residents are for legalizing liquor by the drink," he wrote. ${ }^{77}$

All Iowa eyes then turned to the House. By late April 1963, the House had received petitions from 143,022 Iowans in favor of liquor by the drink and 29,208 opposed. But several complications emerged. A group of southwest Iowa House members threatened to vote against the liquor bill if the Senate raised the Iowa sales tax from 2 to 3 percent to pay for growing state expenses; Representative Conrad Ossian (R-Red Oak), speaking for the group, said, "The number is enough to beat a liquor bill." Some representatives proposed legislation forbidding sales of beer by any establishment other than a licensed liquor establishment, drawing fire from tavern operators and grocery stores that probably would not choose to get liquor licenses but still wanted to sell beer. Others were strongly opposed to the provision allowing city and town councils and county boards of supervisors to have final approval on granting liquor licenses, saying it would put enormous pressure on local officials and make liquor an issue at every council and supervisor election; instead, some favored a vote by the people. Still others insisted that the "implied consent" clause be added to the bill. As the date of debate neared, House supporters were unsure of the bill's future. "I simply don't know what's going to happen," said Representative John Mowry (R-Marshalltown), the bill's floor leader. "I'm not even sure which day we'll take it up." Hughes predicted that the House would pass reform by one vote, saying, "It will be a bloody and close battle." 78

77. Cedar Rapids Gazette, 4/14/1963, 4/15/1963.

78. Cedar Rapids Gazette, 4/24/1963, 4/26/1963, 4/28/1963; Des Moines Register, 4/23/1963, 4/28/1963, 4/30/1963. 
On Wednesday, May 1, 1963, the House began debate by voting down a so-called "dry" amendment, 59-49, which would have defined beer as an intoxicating beverage, banning package sales of beer at grocery and drug stores. By defeating that amendment, the House made the Senate bill the liquor vehicle. The likelihood of passage brightened when the block of anti-sales tax representatives indicated their support for the bill since it looked like the 3 percent tax would go down to defeat in the Senate. In turn, liquor-by-the-drink supporters selected the leader of the anti-tax group, Representative Bill Scherle (RHenderson), to direct the bill in the House. Later that day, the House passed the "implied consent" amendment, 79-29, incorporating into the bill a mandate that motorists under arrest for drinking must take a chemical test for intoxication or automatically lose their license. By then, even "dry" House members conceded that a bill would pass. Charles Grassley, who, along with nine others, had proposed the implied consent amendment, said, "Many sincere drys want to be able to vote for liquor by the drink. They have conditioned their action on the acceptance of implied consent by the Senate." While noting that "I would like to see liquor by the drink killed every place," he admitted, "It appears that liquor by the drink will pass this session." 79

The final House bill was shaped by votes and compromises over the next few days. By 71-37, members voted down an effort to give counties the right to vote "wet" or "dry" every four years when petitioned by 10 percent of those voting for governor in the most recent election. The goal was to make it plain that counties could not have liquor by the drink unless they voted for it. Known as the "dry local option," this meant that a county would be "dry" unless it voted itself "wet," in contrast to the "wet local option," which would allow counties to vote themselves "dry." The House agreed to the latter, allowing people to vote their areas "dry" in special elections. By a vote of 53-51, House members also removed the ceiling on the number of licenses that could be issued for sale of liquor by the drink by a city or town council or a county board of supervisors; supporters argued that this would eliminate any under-the-table bidding

79. Des Moines Register, 5/1/1963, 5/2/1963; Cedar Rapids Gazette, 5/1/1963, 5/2/1963. 
for licenses, permitting market demand and the public through elected officials to determine the number of establishments. The vote also removed the provision limiting licenses to within city business districts. The House version created an enforcement provision authorizing the Iowa Liquor Control Commission to police liquor operations throughout the state. Key clubs, which were at the center of so much debate over the years, were legislated out of existence; rather than granting Iowans the right to bring their own bottles of liquor to store and pour at establishments, legislators, hoping to improve enforcement, granted businesses the right to serve drinks to customers. ${ }^{80}$

On May 3, the Iowa House passed its liquor-by-the-drink bill, $68-40$, a more lopsided vote than anyone would have predicted months earlier. With all 108 members voting, 45 Republicans and 23 Democrats voted for it and 34 Republicans and 6 Democrats opposed it. The Cedar Rapids Gazette's Nye again added up the pro and con county totals based on county populations, showing that the 68 yes votes represented 2,073,898 residents and the 40 no votes represented 683,639 , a 3 to 1 margin. In a statement issued on the day of the House passage, Governor Hughes specifically cited for special commendation "the many members of the House from nonurban areas who voted for this bill, doing what they thought was right despite great pressure of a highly emotional nature from their home districts." He added, "This bill will control liquor-by-the-drink, for the first time since Iowa became a state in 1846. We have had for the past 107 years hypocrisy, double standards of law enforcement, dry laws and a wet state. We have never had adequate liquor control. Today's action by the House is a step toward bringing this to an end." 81

The final legislative stage was for the Senate to concur with the House amendments. The Senate passed the bill, 27-23, on May 9, gaining the vote of an additional senator with passage of the "wet local option" feature. The bill then went to Hughes for his signature. Even after the agreement of both chambers, some looked upon the bill's passage with gloom. Senator Franklin

80. Cedar Rapids Gazette, 5/2/1963, 5/3/1963, 5/4/1963; Des Moines Register, 5/3/1963, 5/5/1963.

81. Cedar Rapids Gazette, 5/6/1963; Des Moines Register, 5/4/1963; “Statement by Harold E. Hughes," Press Releases January-June 1963, box 25, HEH Papers. 
Main (D-Lamoni) said, "We are approaching a brink of moral decay with the passage of this bill." Others cited historical change. Representative John Murray (D-Fort Dodge) believed that the law would end "an age of hypocrisy and disrespect for the law." Still others were even-handed. According to Senator Donald Beneke (R-Laurens), “This liquor bill won't produce the dire results the drys predict or the rosy future for Iowa the wets predict." 82

For the man who was the force behind the changeGovernor Harold E. Hughes - the bill's passage was "statesmanship of the highest order." At the signing ceremony on Tuesday morning, May 14, 1963, Hughes said, "It is the peculiar genius of democracy that persons with diverse points of view can get together and work out solutions to complex problems that are in the public interest. In my opinion, this is exactly what happened with this liquor bill. ... Those who followed the development of this legislation were amazed at the way wets and dries, Republicans and Democrats, worked together patiently, subordinating their individual interests to the interest of the state as a whole." 83

THE LAW went into effect on July 4, 1963, and the Iowa Liquor Commission began to issue licenses the day after the holiday. Within days, the commission had approved 567 licenses for establishments scattered throughout 64 of Iowa's 99 counties. By the end of the month, 91 counties had liquor by the drink. Over the next year, the commission issued 2,452 licenses. Iowa liquor sales to over-the-counter buyers in the first year of liquor-by-the-drink legalization was $\$ 11,778,048$ out of the total of $\$ 49,778,394$ in state liquor, wine, and ale sales, an increase of more than $\$ 5$ million from the previous fiscal year. It was impossible to estimate sales of liquor drinks - and state income that was not collected-from prior years, but presumably most over-the-counter liquor sales in fiscal year 1964 were legal and taxed. The State of Iowa collected more than $\$ 3$ million through

82. Cedar Rapids Gazette, 5/9/1963; Des Moines Register, 5/4/1963.

83. Cedar Rapids Gazette, 5/14/1963; “Governor Harold Hughes, Comments on Signing of Liquor Bill, May 14, 1963," Press Releases January-June 1963, box 25, HEH Papers. 
the 10 percent per drink tax, part of the overall $\$ 19$ million from state liquor sales contributed to the state's General Fund and local city, town, and county governments in fiscal year 1964 . The state was well on its way to collecting taxes on liquor sales that it had missed in prior years. ${ }^{84}$

By 1970, the Liquor Commission was issuing 3,172 licenses annually, earning $\$ 1,175,675$ for the state. By then, the liquorper-drink tax had increased to 15 percent and was contributing $\$ 3,271,619$ to state and local governments. In addition, a 3 percent sales tax that went into effect in 1967 brought in $\$ 1,623,384$ to the state coffers from over-the-counter liquor sales. The amount of liquor sold to licensees through Iowa monopoly stores totaled $\$ 21,481,666$, with the state earning profits from those sales. Liquor by the drink was contributing to the budgets of both state and local governments - and it was legal and regulated throughout the state. 85

WITH THE PASSAGE of liquor by the drink in 1963, legal alcohol availability among adults within Iowa became settled policy, ending a conflict that had raged in the state since its beginning. To date, there have been no significant efforts by Iowa legislators or governors to pull back liquor sales from the general adult population. This debate's demise accompanied the transition of Iowa from a state with powerful rural interests that kept liquor limitations alive as a political issue to one of more urban sensibilities more tolerant of alcohol consumption.

Alcohol consumption and distribution were certainly political issues in Iowa after 1963, but never in relation to limiting the general adult population's access to liquor. Throughout the 1970s and 1980s, the minimum legal drinking age in Iowa fluctuated from 21 to 19 to 18 and finally back to 21 . Efforts to curb drunken driving prompted legislators to establish minimum legal blood

84. Des Moines Register, 7/3/1963, 7/10/1963, 7/15/1963, 7/27/1963; Thirtieth Annual Report of the Iowa Liquor Control Commission for Fiscal Year Ending June 30, 1964, pp. 5, 7, 8 .

85. Thirty-sixth Annual Report of the Iowa Liquor Control Commission for the Fiscal Year Ending June 30, 1970, pp. 6, 12; Iowa Department of Revenue, "Iowa Tax Rate History, History of Iowa Sales and Use Tax Rates," https://tax.iowa.gov/ iowa-tax-rate-history\#sales. 
alcohol levels and set strict fines, jail time, and driver's license confiscation for violators. During the Farm Crisis of the 1980s, Iowa political leaders, who were looking for reductions in state expenses, eliminated state liquor monopoly stores and shifted to distribution through private businesses.

The fundamental reason for the end of this debate on overthe-counter liquor access in Iowa is that Iowans wanted it to end. In the nineteenth century, clear majorities of Iowa voters wanted prohibition - as shown in the popular votes of 1847 and 1882though enforcement was a significant challenge. Politicians tried to chart courses between the desire to eliminate liquor and the reality that some Iowans wanted to continue to drink alcohol. Prohibition returned in the early twentieth century, but Iowans showed that their attitudes were changing by narrowly rejecting state constitutional prohibition in 1917 and voting for repeal of national prohibition in 1933. In 1934 Iowans turned to a state monopoly distribution system to manage and control liquor sales, but soon residents, wanting expanded availability, voted with their actions by defying the law in many quarters. When Harold Hughes gave Iowans a clear choice in 1962 to open the state to liquor by the drink, they voted him into office. That was not the only issue in the campaign, but it was a significant one, and his victory was seen as a mandate to change Iowa's liquor laws. Given the tools of government, Hughes - with bipartisan support in the Iowa legislature-aggressively fought to accommodate the will of Iowans of the time. This reform of Iowa's liquor laws closed a debate among Iowans that had been fought for over a century, making it Iowa's last liquor battle. 